\title{
Isolation of Total RNA from a Freshwater Green Alga, Zygnema cruciatum, Containing High Levels of Pigments
}

\author{
Jong Won Han ${ }^{1}$, Minchul Yoon ${ }^{2}$, Key Pyoung Lee ${ }^{1}$ and Gwang Hoon Kim ${ }^{2 *}$ \\ ${ }^{1}$ Department of Chemistry, Kongju National University, Kongju, 314-701, Korea \\ ${ }^{2}$ Department of Biology, Kongju National University, Kongju, 314-701, Korea
}

\begin{abstract}
Conventional methods for the isolation and purification of mRNA from Zygnema were unsuccessful because of its high amount of pigments and RNA interactive molecules. In particular, pigments were difficult to remove using conventional protocols because they interacted with RNA during pulverization of the materials. This resulted in total degeneration of RNA in two to three hours. To alleviate this problem, we developed an isolation method that utilized DEAE-cellulose resin. The pigments bound to DEAE anion exchange resin and separated from the RNA. Purified total RNA showed an yield of $50 \mu \mathrm{g}$ per $100 \mathrm{mg}$ of tissue with this method. The amplified $2^{\text {nd }}$ strand cDNA was distributed $300 \mathrm{bp}$ and over.
\end{abstract}

Key Words: DEAE-cellulose, freshwater green alga, total RNA, Zygnema cruciatum

\section{INTRODUCTION}

For the study of gene transcription, obtaining total intact RNA is very important. But it is difficult to get intact RNA from some plants. This is mainly because of high contents of polysaccharides, pigments, and other unidentified compounds in these plants (Wang et al. 2004). This causes problems by interfering in RNA experiments such as a RT-PCR, DD-RT-PCR or Northern blot analysis. Various protocols for RNA isolation have been reported for plants containing high levels of polysaccharides and pigments which overcome the above mentioned limitations (Gao et al. 2001; Tai et al. 2004; Tao et al. 2004; Wang et al. 2004; Meisel et al. 2005; Birtić and Kranner 2006; Salter and conlon 2007). However, some plant materials have not yet been studied using these modified methods.

Zygnema spp. are well known freshwater conjugating green algae that form free floating mats in shallow waters (Kim et al. 2007). Zygnema spp. have been reported in every biome from tundra through boreal forest to tropical rain forest and desert chaparral. It is one of few filamentous freshwater algae that lives in the Arctic as well as the Antarctic (Hawes 1989). However, little is known regarding gene transcription and translation in

*Corresponding author (ghkim@kongju.ac.kr) this complex. Because of high pigment amounts and RNA interactive molecules, it has been impossible to isolate and purify mRNA from Zygnema using conventional methods. In this paper we describe the development of a new method of RNA isolation using DEAE-cellulose resin and compare the results with other RNA isolation methods.

\section{MATERIALS AND METHODS}

\section{Plant material}

Zygnema cruciatum was collected from ponds near Kongju University in Korea. The collected plant material was washed three times with distilled water and maintained in Bold's basal medium (Bischoff and Bold 1963) with a day length of 12:12 h (L:D) and an irradiance of 20 $\mu$ mol photon $\mathrm{m}^{-2} \mathrm{~s}^{-1}$ at $4^{\circ} \mathrm{C}$.

\section{Reagents}

All solutions were treated with $0.1 \%(\mathrm{v} / \mathrm{v})$ diethylpyrocarbonate (DEPC) except Tris buffer, which was prepared with DEPC-treated distilled water. RNase-free glasswares were prepared by wrapping in aluminum foil and baking at $180^{\circ} \mathrm{C}$ for $12 \mathrm{~h}$. The plastic wares were soaked in freshly prepared $0.1 \%$ DEPC for $12 \mathrm{~h}$ at room temperature and then autoclaved.

The extraction buffer consisted of 1.5\% SDS, $200 \mathrm{mM}$ Tris-Cl (pH 8.3), 50 mM EDTA, and 10 mM DTT. The 
DTT was added just before use. Phenol-chloroformisoamylalcohol (25:24:1) was equilibrated with Tris-Cl ( $\mathrm{pH}$ 8.0). Phenol-chloroform (5:1) was equilibrated with citrate buffer ( $\mathrm{pH}$ 4.0). DEAE-cellulose was equilibrated with $200 \mathrm{mM}$ Tris-Cl (pH 8.0). A spin type column was used.

\section{RNA extraction protocol}

$100 \mathrm{mg}$ of Zygnema cruciatum was ground to a fine powder under liquid nitrogen using mortar and pestle. The powder was transferred into $1 \mathrm{~mL}$ of extraction buffer and mixed vigorously. The mixture was added to an equal volume of saturated Phenol/chloroform/ isoamylalcohol (25:24:1), vortexed for $20 \mathrm{sec}$ and incubated at room temperature for $10 \mathrm{~min}$. After centrifugation at $12,000 \mathrm{~g}$ for $10 \mathrm{~min}$ at $4^{\circ} \mathrm{C}$, the upper aqueous phase (about $800 \mu \mathrm{L}$ ) was loaded onto a spin type column with pre-equilibrated $2 \mathrm{~mL}$ of DEAE-cellulose anion-exchange resin ( $50 \%$ suspension). The column was centrifuged for $30 \mathrm{sec}$ at room temperature. The non-bound sample fraction was collected and an equal volume of isopropyl alcohol was added to sample and incubated for $10 \mathrm{~min}$ at room temperature. The mixture was centrifuged at $20,000 \mathrm{~g}$ for $10 \mathrm{~min}$ at $4^{\circ} \mathrm{C}$. The supernatant layer was discarded and the pellet was washed with $1 \mathrm{~mL}$ of $70 \%$ ethanol. The pellet was dissolved with DEPC treated water and the purified RNA sample was treated with 5 units of DNase I (Promega, USA) for $30 \mathrm{~min}$ at $37^{\circ} \mathrm{C}$. Following digestion, the mixture was incubated at $70^{\circ} \mathrm{C}$ for $10 \mathrm{~min}$. To remove contaminants, $100 \mu \mathrm{L}$ of phenolchloroform (5:1, $\mathrm{pH} 4.0)$ was added to the sample tube and vortexed for $20 \mathrm{sec}$, incubated for $10 \mathrm{~min}$ and then centrifuged at $12,000 \mathrm{~g}$ for $10 \mathrm{~min}$ at $4^{\circ} \mathrm{C}$. The upper aqueous phase was transferred to a new micro tube. The aqueous phase was mixed to $1 / 10$ volume of $3 \mathrm{M}$ sodium acetate and 2.5 volume of $100 \%$ Ethanol. The mixture was incubated at $-70^{\circ} \mathrm{C}$ for $30 \mathrm{~min}$ and then centrifuged for $10 \mathrm{~min}$ at 20,000g. Total RNA was washed with $1 \mathrm{~mL}$ of $70 \%$ Ethanol and the purified total RNA was dissolved in DEPC-DW.

\section{Other methods for RNA isolation}

Other standard and modified methods for RNA isolation were used to compare with our method. TRI reagent based on acid guanidium thiocyanate-phenol-chloroform extraction methodology (Chomczynski and Sacchi 1987) was used according to manufacture's protocol. The $\mathrm{LiCl}_{2}$ precipitation method was used according to Gao et al. (2001).

\section{RNA analysis}

The RNA concentration was determined spectrophotometrically using UV-Vis spectrophotometer. U-3300 (HITACHI Ltd, Tokyo, Japan). The RNA quality was determined based on absorbance at $\mathrm{OD}_{260} / \mathrm{OD}_{280}$ and its integrity was assessed by electrophoresis in 1.2\% formaldehyde gels (Sambrook and Russell 2001).

\section{First strand cDNA synthesis and amplification of sec- ond strand cDNA}

$1 \mu \mathrm{g}$ of total RNA was used for first strand cDNA synthesis using Roche RT-reaction kit (Roche, USA) following the manufacturer's protocol. The synthesized first strand of cDNA was amplified with random primer and oligo-dT primer using Taq-DNA polymerase. The amplified cDNA was visualized using $1.5 \%$ agarose gel electrophoresis.

\section{High-performance liquid chromatography (HPLC)}

$20 \mu \mathrm{g}$ of purified total RNA was injected and analyzed by HPLC (GILSON, USA) using a reverse phase C18 column (TOSOH, TSK-gel ODS-100V $5 \mu \mathrm{m}$ ) with a $0-50 \%$ (10 $\mathrm{min}$ ), $50-80 \%$ (30 $\mathrm{min}), 80-100 \%$ (40 $\mathrm{min}$ ) gradient of organic solvent (Acetonitrile, $0.05 \%$ TFA). Chromatograms were recorded at a wavelength of $260 \mathrm{~nm}$. Isolated pigments were identified spectrally.

\section{RESULTS AND DISCUSSION}

TRI reagent based on acid guanidium thiocyanate-phenol-chloroform extraction (Chomczynski and Sacchi 1987) and $\mathrm{LiCl}_{2}$ methods (Gao et al. 2001) have been successfully used to isolate total RNA from many different organisms containing high level of starches and pigments. However, isolation of total RNA from Zygnema cruciatum was not possible either by TRI reagent based methods or by $\mathrm{LiCl}_{2}$ methods. Total RNA extracted using either method yielded heavily contaminated RNA with some black pigments (Fig. 1). Modifications of both methods were unsuccessful in removing the pigments (data not shown). The contaminating pigments contributed to an inaccurate quantification of RNA when using a spectrophotometer (Lagonigro et al. 2004). Although the isolated fraction from TRI reagent methods showed high absorbance at $260 \mathrm{~nm}$ (Table 1), the RNA was not detected by formaldehyde gel electrophoresis (Fig. 2). Nor could the $\mathrm{LiCl}_{2}$ precipitation method with SDS-Phenol solve this problem. Although the isolated 


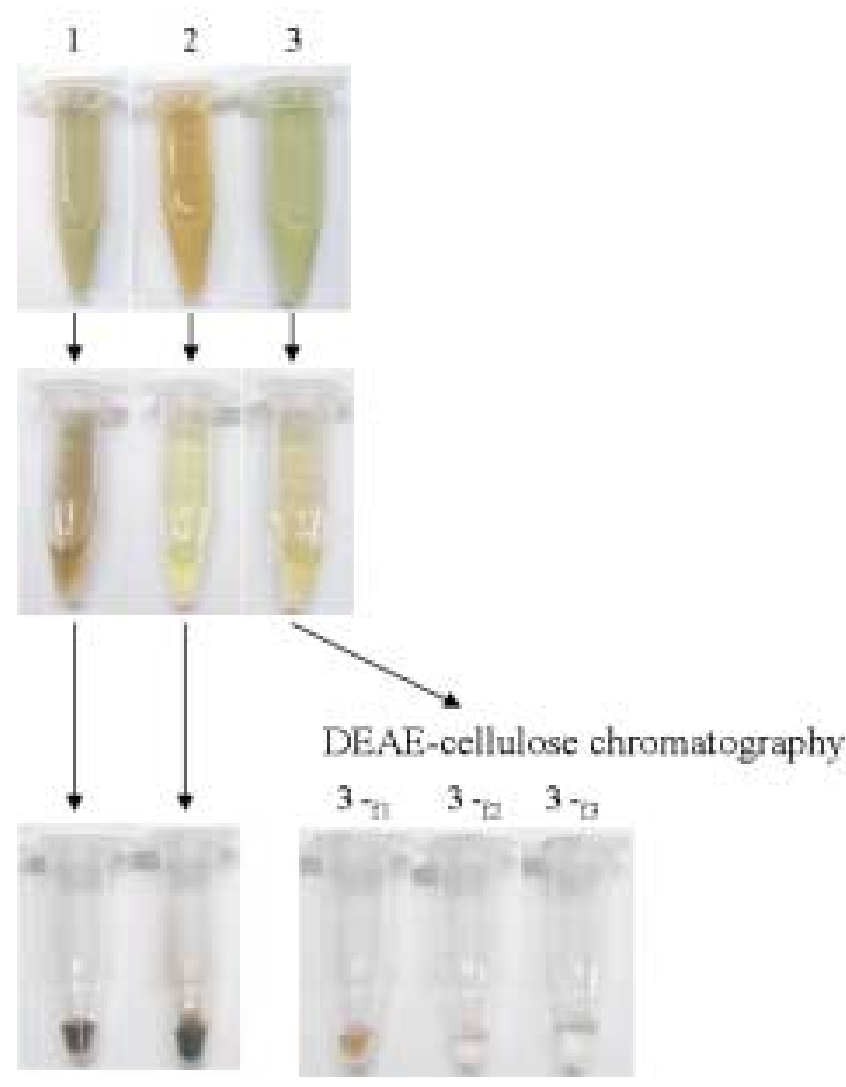

Fig. 1. Discoloration of isolated RNA by the pigments of Zygnema cruciatum. The pigments were not removed by TRI reagent methods or by $\mathrm{LiCl}_{2}$ method. Note that DEAEcellulose resin could remove the pigments. $1: \mathrm{LiCl}_{2}$ method; 2: TRI reagent method; 3: This study; treatment with $100 \mu \mathrm{L}$ $(1 / 5, \mathrm{f} 1), 300 \mu \mathrm{L}(3 / 5, \mathrm{f} 2), 500 \mu \mathrm{L}(1 / 1, \mathrm{f} 3)$ of DEAE-cellulose.

Table 1. Comparison of isolated RNA of Zygnema cruciatum using different isolation methods

\begin{tabular}{|c|c|c|c|c|}
\hline \multirow{2}{*}{ Method } & \multicolumn{2}{|c|}{ Absorbance (nm) } & \multirow{2}{*}{$\mathrm{OD}_{260} / \mathrm{OD}_{280}$} & \multirow{2}{*}{$\mathrm{RNA} \mu \mathrm{g} / \mathrm{mL}$} \\
\hline & 260 & 280 & & \\
\hline $\mathrm{LiCl}_{2}$ & 0.593 & 0.447 & 1.32 & 2372 \\
\hline TRI reagent & 0.346 & 0.276 & 1.25 & 1384 \\
\hline \multicolumn{5}{|l|}{ This study } \\
\hline $\mathrm{DEAE}_{-\mathrm{f} 1}$ & 0.512 & 0.329 & 1.55 & 2048 \\
\hline DEAE- $_{-22}$ & 0.326 & 0.178 & 1.83 & 1304 \\
\hline $\mathrm{DEAE}_{-\mathrm{f3}}{ }^{*}$ & 0.222 & 0.129 & 1.72 & 888 \\
\hline $\mathrm{DEAE}_{-\mathrm{e} 1}$ & 0.01 & 0.006 & 1.66 & 40 \\
\hline DEAE-e2 & 0.024 & 0.016 & 1.50 & 96 \\
\hline DEAE- $_{\mathrm{e} 3}$ & 0.019 & 0.011 & 1.72 & 76 \\
\hline
\end{tabular}

$\mathrm{LiCl}_{2}$ : $\mathrm{LiCl}_{2}$ method; TRI reagent: TRI reagent method; This study: DEAE-cellulose chromatography (f: flow-through fraction, e: eluted fraction; f1, e1: 1/5 ratio (Resin/Extraction buffer, $\mathrm{v} / \mathrm{v}), \mathrm{f} 2, \mathrm{e} 2 \mathrm{:} 3 / 5(\mathrm{v} / \mathrm{v}), \mathrm{f} 3, \mathrm{e} 3: 1 / 1(\mathrm{v} / \mathrm{v}))^{*}$ : optimized condition.

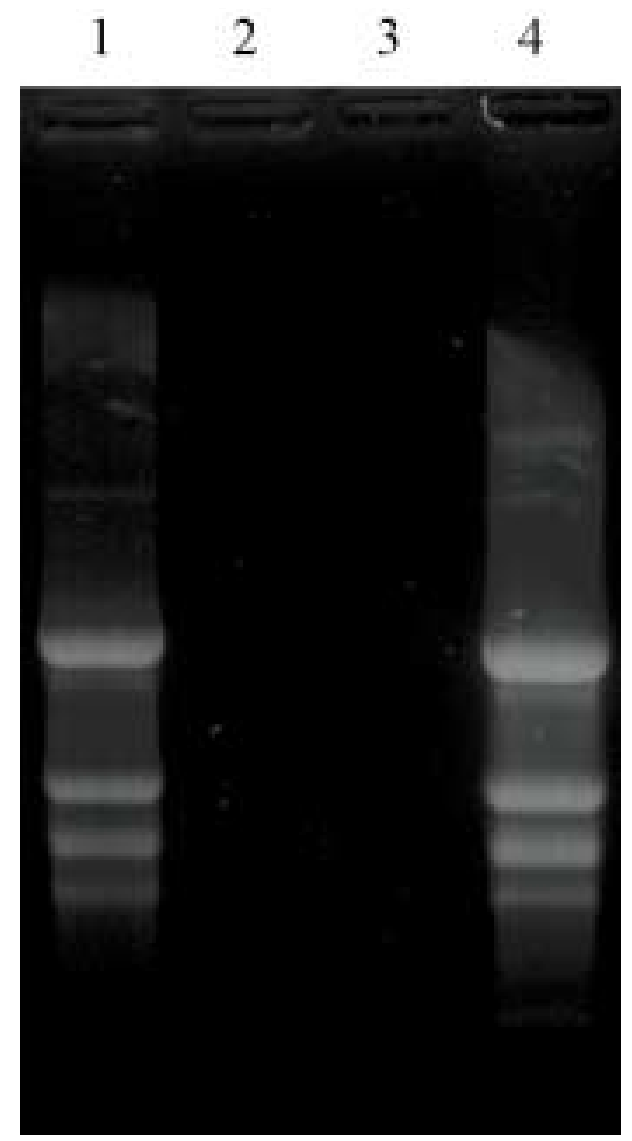

Fig. 2. Results of $1.2 \%$ formaldehyde gel electrophoresis of total RNA isolated using different methods. No RNA was detected in the faction isolated by TRI reagent methods. Lane 1: $\mathrm{LiCl}_{2}$ method; lane 2: TRI reagent method; lane 3: modified TRI reagent method; lane 4: Our method.

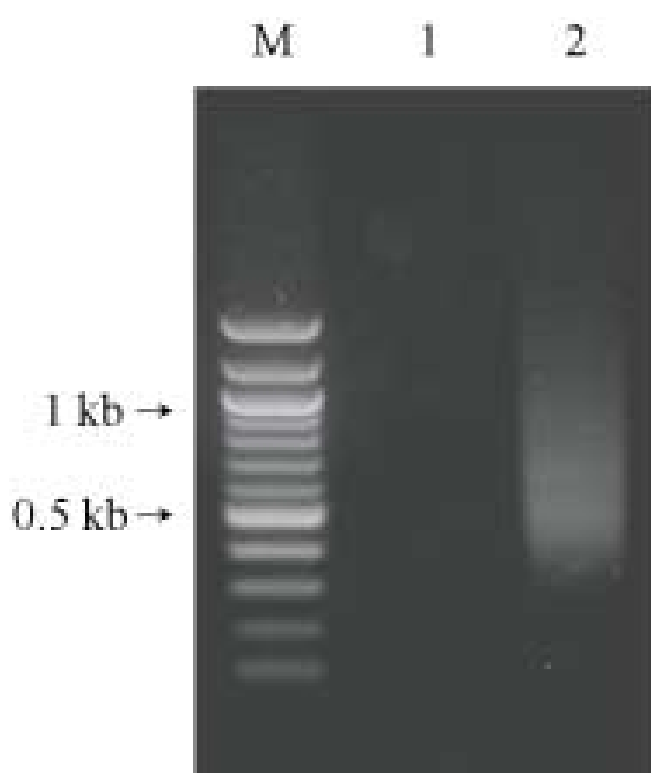

Fig. 3. Agarose gel electrophoresis of amplified $2^{\text {nd }}$ strand cDNA from isolated total RNA using different methods. M: 100 bp DNA Ladder; lane 1: $\mathrm{LiCl}_{2}$ method; lane 2: Our method. 


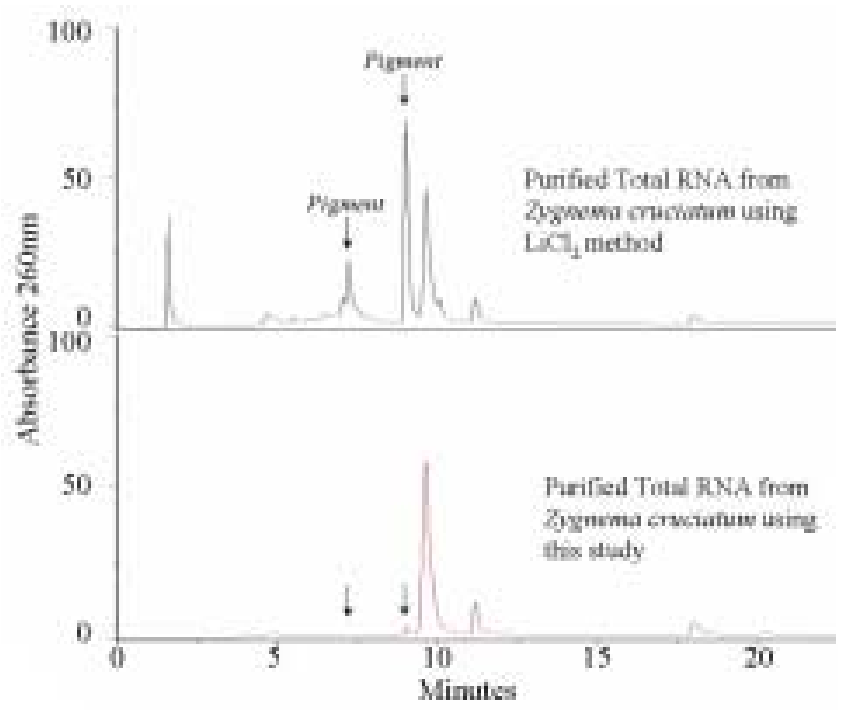

Fig. 4. Analysis of purified RNA from Zygnema criciatum by high performance liquid chromatography.

RNA was detected by gel electrophoresis, the contaminating pigment was not removed (Figs 1,2). The pigment appeared to degenerate RNA. When first strand cDNA was synthesized from the RNA isolated with the $\mathrm{LiCl}_{2}$ precipitation method, it was not detected on agarose gel (Fig. 3). This might be caused by a large number of free carboxylic acid residues in the pigments bound to charged molecules, such as thermo-stable DNA polymerase (Eckhart et al. 2000) and reverse transcriptase (Price and Linge 1999).

Some of the chemical properties of the pigments were similar to RNA molecules. The pigments were not separated by organic solvents such as acetone, ethanol, methanol and phenol (data not shown), but they were readily separated in the aqueous-phase, and precipitated with RNA molecules by isopropanol, high salt and $\mathrm{LiCl}_{2}$. In the HPLC analysis, the pigments appeared at $9 \mathrm{~min}$ of retention time and RNA at 10 min (Fig. 4). However, RNA did not interact with anion exchange resin where the pigments bound strongly. When the cell extracts were run through DEAE anion exchange resin, the pigments disappeared in accordance with the amount of the resin (Fig. 1). The optimal ratio was determined as 1:1 $(\mathrm{v} / \mathrm{v})$. At this ratio we could isolate intact total RNA without pigment contamination (Figs 1, 2). The eluted fraction from the column had almost no RNA, suggesting that RNA did not bind to the resin (Table 1). When the purity of isolated RNA was analyzed using HPLC, the pigment peak disappeared after DEAE anion exchange resin treatment (Fig. 4). Second strand cDNA was successfully made with the RNA isolated using this

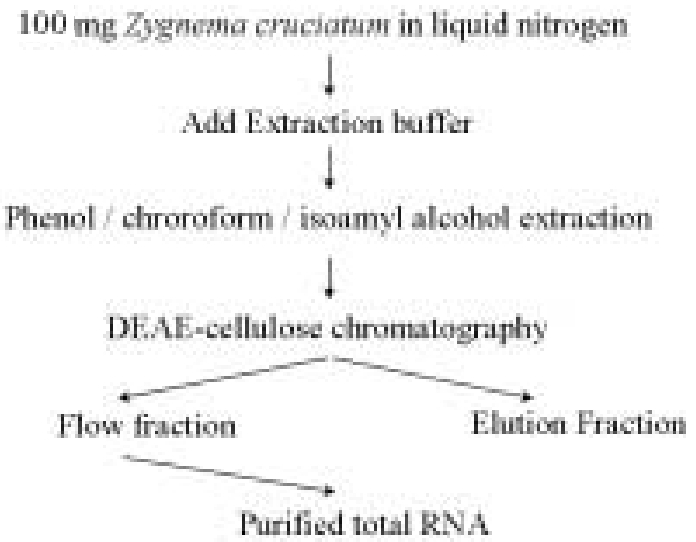

Fig. 5. Total RNA purification strategy using DEAE-cellulose chromatography.

method (Fig. 3). The RNA purification strategy using DEAE-cellulose chromatography is shown in Fig. 5.

\section{ACKNOWLEDGEMENT}

This work was supported by National Research Laboratory grant from KOSEF to GHK.

\section{REFERENCES}

Birtić S. and Kranner I. 2006. Isolation of high-quality RNA from polyphenol-polysaccharide- and lipid-rich seeds. Phytochem. Anal. 17: 144-8.

Bischoff H. and Bold H.C. 1963. Phycological studies IV. Some soil algae from Enchanted Rock and related algal species. Univ. Tex. Publ. No. 6318, Austin.

Chomczynski P. and Sacchi N. 1987. Single-step method of RNA isolation by acid guanidium thiocyanate-phenol-chloroform extraction. Anal. Biochem. 162: 156-159.

Eckhart L., Bach J., Ban J. and Tschachler. 2000. Melanin binds reversibly to thermostable DNA polymerase and inhibits its activity. Biochem. Biophys. Res. Commun. 271: 726-730.

Gao J., Liu J., Li B. and Li Z. 2001. Isolation and purification of functional total RNA from blue-grained Wheat endosperm tissues containing high levels of starches and flavonoids. Plant Mol. Biol. Rep. 19: 185a-185i.

Hawes I. 1989. Filamentous green algae in freshwater streams on Signy Island, Antarctica. Hydrobiologia 172: 1-18.

Kim G.H., Yoon M.C., West, J.A., Klochkova T.A. and Kim S.H. 2007. Possible surface carbohydrates involved in signaling during conjugation process in Zygnema cruciatum monitored with FITC-lectins (Zygnemataceae, Chlorophyta). Phycol. Res. 55: 135-142.

Lagonigro M.S., Cecco L.D., Carninci P., Stasi D.D., Ranzani T., Rodolfo M. and Gariboldi M. 2004. CTAB-Urea method purifies RNA from melanin for cDNA microarray analysis. Pigment Cell Res. 17: 312-315.

Meisel L., Fonseca B., González S., Baeza-Yates R., Cambiazo V. 
Campos R., Gonźalez M., Orellana A., Retamales J. and Silva H. 2005. A rapid and efficient method for purifying high quality total RNA from peaches (Prunus persica) for functional genomics analyses. Biol. Res. 38: 83-8.

Price K. and Linge C. 1999. The presence of melanin in genomic DNA isolated from pigmented cell lines interferes with successful polymerase chain reaction: a solution. Melanoma Res. 9: 5-9.

Salter MG. and Conlon HE. 2007. Extraction of plant RNA. Methods Mol. Biol. 362: 309-14.

Sambrook J. and Russell D.W. 2001. Molecular Cloning: A Laboratory Manual, Cold Spring Harbor Lab. Press, Plainview, NY.
Tai H.H., Pelletier C. and Beardmore T. 2004. Total RNA isolation from Picea mariana dry seed. Plant Mol Biol Rep. 22: 93a93e.

Tao N., Cheng Y., Xu J., Xu Q. and Deng X. 2004. An effective protocol for the isolation of RNA from the pulp of repening citrus fruits. Plant Mol. Biol. Rep. 22: 305a-305f.

Wang D., Wang B., Li B., Duan C. and Zhang J. 2004. Extraction of total RNA from Chrysanthemum containing high levels of phenolic and carbohydrates. Colloids Surf. B. Biointerfaces 36: 111-4.

Received 20 May 2007

Accepted 15 June 2007 
